\title{
Steps towards an ecology of cognition: A holistic essay
}

\author{
Sabine Brauckmann \\ Elisabeth-Ney-Str. 1, D-48147 Münster, Germany \\ e-mail: brauckm@uni-muenster.de
}

\begin{abstract}
The essay informs on Gregory Bateson's holistic approach towards an epistemic view of nature. The ecology of mind relies upon a biological holism serving as a methodic tool to explain living "phenomena", like, e.g., communication, learning, and cognition. Starting from the idea, the smallest unit of information, Bateson developed a type hierarchy of learning that is based on a cybernetic view of mind. The communication model focuses on paradoxa caused by false signification. It leads to a pathogenesis of sckizophrenia that is subsumed under the conception of double binds. This ecosystemic perspective of living processes represents a truly (w)holistic theory of nature.
\end{abstract}

In spring, when woods are getting green, I'll try and tell you what I mean. [...] In autumn, when the leaves are brown, take pen and ink, and write it down.

Humpty-Dumpty's song (Carroll 1899: 129)

\section{Some preliminary remarks on holism}

It was in spring 1998 when I gave a series of lectures on holism in the sciences covering physics, mathematics and biology at the Institute of Semiotics in Tartu. ${ }^{1}$ It culminated in a discussion of Gregory Bate-

\footnotetext{
My thanks belong to Peeter Torop and Kalevi Kull who invited me to this adventurous task. Without the patience and tolerance of the audience, the students of semiotics, I could not have fulfilled it. Their awareness was more than encouraging.
} 
son's cybernetic approach towards a holistic epistemology that focuses on us humans, and how we cope with our environment, or know about it. Since then time has past, and I am still thinking about holism and its impact on the natural sciences, particularly on the biological sciences. Now it is autumn 2000, and I will discuss this crucial issue again, but this time with pen and paper instead of chalk and blackboard. $^{2}$

The objective of my lectures series was to show the virtue of shifting from ontology to epistemology and backwards by the means of a concept named holism. For historians and philosopher of science there does not exist any doubt, that this concept was and, maybe still is, at the centre of fundamental changes in various areas of philosophy and the sciences in the 20th century. Some versions of holism that deal with intentional phenomena are widespread among analytic philosophers subsequent to the work of Ludwig Wittgenstein and Quine's "Two Dogmas of Empiricism". For the sciences holism is considered as an option as, for example, the Copenhagen interpretation of quantum mechanics, Gestalt theory of psychology or the organismic view of biology have shown. The biological holism that is particular of interest for my own research on theoretical biology, intended to refute or, at least, to correct the strong version of genetic determinism which became a paradigm for biological sciences. Opting for holism in any of these areas has far-reaching consequences for our view on nature and ourselves as well. In general, the point of my inquiry into the different forms of holism is to assess their impact on the development of the natural sciences.

The biological holism of the 20th century continued a controversy that started in the 19th century. The point of departure was the crucial issue, whether organisms are (physical) machines, or whether they exhibit properties that cannot be described by physico-chemical methods and principles. This question was initiated by the Cartesian statement that the laws of nature are identical with the ones of classical mechanics. A fundamental feature of the mechanistic way of thinking is a reductionism filtering out complex events of nature to singular states or processes to investigate them with the techniques of physics and mathematical methods.

\footnotetext{
2 As this is mere an essay, I consciously avoid to bother the reader with the extensive German style of quotations. However, if the reader is interested, he and she might find the bibliography useful.
} 
As opposed to mechanism, neovitalism stated that all living phenomena as embryogenesis, the development and growth of organs can be deduced from a trans-biological principle, namely the entelechy, whereas the mechanistic counterpart argumented by the machine metaphor. To overcome this time-wasting discussion, holistic approaches claimed that organisms are functioning like systems structured by their own inherent lawfulness. By it these living entities are connected with their internal subsystems and, at the same time, with their external environment. The trick here was that holism was converted from an ontic entity to a methodic tool which could be accepted by scientists working in laboratories.

As a purely metaphysical concept holism is as old as philosophy itself; you can think of Plato, Pascal, Leibniz, Goethe, Hegel, Whitehead among many others as thinkers who proposed holistic approaches to explain the world. Partly it is analogous to the idea or Weltanschauung that ancient Greek philosophy subsumed under the concept of $\alpha \rho \mu$ ove1 $\alpha$ that synthesizes complex components to a whole entity. For example, Plato wrote in the Sophistes "to develop is always towards a whole" - this is an ontic approach. Opposed to him, Aristotle mentioned in the Metaphysika that the whole is a system of parts structured in a mutual arrangement that come into being by a holistic and indivisible principle; this is a methodological approach. Kant investigated in the Kritik der Urteilskraft the epistemic version stating that the cause of the mode of existence for every part of a living body is included in the whole. Furthermore, he defined a functioning organism as a living being that is demarcated due to its own properties against its physico-chemical surroundings. But, simultaneously the organism constructs its own specific environment. For Kant the whole-part relationship represents a bivalent relation the members of which belong to the same level. This statement differs significantly from holistic approaches of theoretical biology that demanded for a hierarchic organization of the system involved. The decisive point of the Kantian view was that the whole emerges as the result of its elements, and a part, on the other hand, is determined by the not-yet developed whole. Kant called this a paradox (antinomy) that still holds as you will see when discussing Bateson's epistemic ecology.

The shortest interpretation of holism is the whole is more than the sum of its parts; hence, you have to add the references between the parts to constitute a whole, as Nagel has added. Obviously, it seems to 
be trivial that the part is not the whole, it already follows from the definition of part and whole as Leibniz has done it: If the whole is $A$, the part is $B$, I assume, that $A$ is bigger than $B$, because a part of $A$, namely $B$, is equivalent to $B$ in its whole totality - qoud erat demonstrandum.

The main characteristics of whole systems are that they exhibit emergent macro-properties that cannot be predicted before they have occurred. Not all their properties can be reduced from the properties of the subsystems, and there exists a holistic feedback, or macrodetermination. ${ }^{3}$ Particularly the latter implication has caused fired discussion for it seemed to be absurd stating that one component which interacts with many, sometimes even with all other components, interacts with the system as a whole simultaneously. For critics it means that the logical principle of tertium non datur is faulted. However, holism claimed that real systems are interacting with each other, and no system can be isolated from another under absolute conditions. No doubt, objects are approximately separated - the physicist calls this feature quasiseparable -, since otherwise it would be not possible to gain knowledge about them. In addition, holistic systems exhibit a referential deduction top-down, i.e. the network concept. Finally, there exists the postulate of moral value, or the ecological approach. It means that we should comprehend nature and every living being as the indivisible part of a holistic system which should be protected. This hypothesis has its roots in an ecological definition of organisms as subjects actively being related to their environment as Uexküll has argued.

My series of lectures concluded with the paradigm of Gregory Bateson, a well-known son of a famous father, the British geneticist William Bateson. As the development of modern holism started in psychology, the social sciences and linguistic semantics, it makes sense to concentrate in this holistic essay again on Gregory Bateson. The main question addressed in the following will be how Bateson's cognitive ecology fits these holistic principles. Thus, with pen and ink, I now write down my ideas about the anthropologist, philosopher, poet and naturalist, film director, photographer, and profound holistic thinker Gregory Bateson (1904-1980). ${ }^{4}$

The philosopher Donald Campbell has defined it as downward causation.

4 Here biographical dates will be neglected; for the interested reader I would like to refer to Lipset (1980) and Harries-Jones (1995). 


\section{Gregory Bateson's ecological epistemology}

It is said by some evolutionary theoreticians that the impact of Bateson on cybernetic epistemology is comparable to the one of Darwin on evolution. As far as I can judge it, this is a true overestimation. Nevertheless, he has compared data, principles, and experiences of anthropology, sociology, linguistics, history, psychology, cybernetics and art, and analyzed their structures and developmental processes as maybe nobody else has done in this way. In the broadest sense of the word, he was an anthropologist studying mankind in all its aspects. That was the reason why Bateson's theory fascinated me, and why it was, on the other side, so difficult to grasp its messages. His strong commitment to an elliptic rhetoric has caused more than once confusion and headaches in my brain. As difficult as the terrain may be that we will enter now, I nonetheless hope the reader will enjoy this holistic approach towards a holistic ecology. Bateson wrote on epistemology, and we will investigate his epistemic ecology from an ontic point of view without bothering on the specialty of psychology, anthropology, or evolution. ${ }^{5}$ To anticipate his systemic approach on epistemology Mind here constitutes a component of reality and it is, therefore, encompassed inside nature.

My short treatise aims at clarifying some basic notions like idea, difference, pattern, context, and double-bind. Furthermore, it will discuss the interplay of learning, information and communication. The main objectives are to elaborate Bateson's concept of mind as a feedback system, his learning theory, his communication model that finally resulted in an ecology of mind. Besides the discussion of his holistic epistemology the essay will play with some traits of logical reasoning which have fascinated serious thinkers and clowns as Lewis Carroll and Ludwig Wittgenstein. ${ }^{6}$ My paper relies upon on two books, namely, the Steps toward an Ecology of Mind and Mind and Nature. The collection of articles tried to formulate an ecology of ideas relating questions like, what for an interaction exists between ideas, which economy restricts the manifoldness of ideas inside a specific area of the brain, what are the necessary conditions for the stabil-

Bateson described epistemology as follows: "It is the name of a species of scientific study and talk. We set out to study the nature of study itself, the process of acquisition of information and its storage" (Bateson 1979: 6).

6 Bateson can be called a distant cousin of these two logicians. 
ity or survival of such a system and/or subsystem. The second book calls for the platonic thesis that epistemology is a nondivisible integrated metascience enclosing evolution, thinking, adaptation, embryology and genetics - a science of mind in the broadest sense of the word.

In 1951 he and his Swiss colleague Jürgen Ruesch published their book on Communication (Ruesch, Bateson 1951). At that time he also taught physicians and beatniks at the Californian School of Fine Arts in San Francisco - probably a good source for his double-bind, when you will heave read the anecdote confirming that double binds really exist:

It happened during the first meeting of the class, and I had talked about the cultural differences between England and the States - an issue, that always should related to when an Englishman is teaching Americans on cultural anthropology. At the end of the meeting one of the participants came to me. He had a look behind his shoulder to be sure that all the others were gone and said very slowly: $<$ I would like to ask one question. $>$

$<$ Sure, do it. $>$

$<$ Do you want that we learn what you are telling us? $>$

I hesitated one moment with my answer, and he quickly continued:

$<$ Or is this all a sort of example, an illustration of something? $>$

$<$ Yes, that's it! $>$

$<$ But an example for what? $>$

And nearly one year later I heard some rumour, a sort of complaint. It was said $<$ Bateson knows something which he does not tell us $>$ or $<$ behind the sentences of Bateson, there is something behind all of this, but he never reveals it $>$. Of course, I did not answer the question $<$ an example for what? $>$ ?

\section{The Batesonian concepts}

In his cognitive theory idea represents the smallest unit of a mental process, comparable to the bit of our information age. It denotes a difference that distinguishes itself and is situated on the lowest level of perception, and produces patterns. In his later years Bateson referred to Gustav Theodor Fechner who investigated the "just noticeable difference" meaning that perception depends on difference, contrast and

\footnotetext{
7 This happens when taking Bateson seriously and literally - never forget that Gregory is looking from behind the glasses.
} 
ratio, but not on a specific state of matter-mind. ${ }^{8}$ The logician will be probably remineded of Spinoza's dictum definitio est negatio. That means, when you define something, you implicitly negate its contraposition. What we call in ordinary language idea resembles more a complex aggregate of the units in question. However, even in ordinary language we hesitate to name, for example, the bilateral symmetry of a frog or the message of a single neural impulse as idea as Bateson has done it.

To clarify this concept of difference that Bateson preferred to our common word facts, Kant's transcendental idealism might help, as so often when the issue converts to a philosophical sophistication. A Kantian difference represents an object or phenomenon that consists of a million of potential facts of which just a few will be realized. The realization depends on the observer and his choice. Due to an idea, the observer and the natural phenomenon are interwoven after the observer had sorted out all the other possibilities that the phenomenon offered to him. You could also call it a recursive operation, it is the logical term Bateson might have preferred.

Closely related to difference, not to say, mere another word is the pattern classifying a collection of events or objects that enables us to formulate conjectures. Patterns - a kind of Kantian schemata - refer to the relations between phenomena, things, or events occurring in our environment, and their ability to change the environmental outlook. They are non-material entities that do not emerge as given substances. They are, however, the necessary outward and visible sign of the systems being organized, as Bateson darkly stated. Bateson further explained that the behaviour of animals arises from patterns and forms that are shaped by relations between the animals. The psychologist May described them as the metaphors by which individuals are perceived, and recognized (May 1977: 85f). In an example of frog and fly and how their behavioural pattern are connected, May illustrated the problem of the difference or idea in a very convincing way. A hungry frog sees a fly moving around its head. With the first fly movements the frog takes aim, and the second time when the fly moves the frog gulps it up. Thus, the frog could perceive the fly because the flying animal differed from the frog's environment.

8 For a further elaboration of Fechner, Fechner's law on the efferent side of the central nervous system, and for the philosophy of anomal monism, cf. Heidelberger (1993) and Davidson (1980). 
The patterns, or Kantian schemata based on our imagination, perception and thinking, are swirling around us and inside us, intertwining the phenomena of the environment with our mental states and building up a referential network that we call "our universe". 9 For Bateson as for Kant and, in his succession, for Uexküll ${ }^{10}$ we humans create our world by applying our schemata, and categorize the world in that way as we see it behind our eyes. Schemata are fixed as invariants, or primary categorization for they do not depend on culture or language, education or upbringing, we are born with them. For Bateson they are floating images along interfaces whereby the redundancy of all the possibilities that nature offers us, is limited. Interfaces are stretched out between the nervous system transferring the message of a difference, and the environment. They refer to systems' boundaries defined by an information exchange and by changes in coding, rather than to enclosures like our skin. ${ }^{11}$

You can compare the Batesonian patterns to Cassirer's thought and perception schemes that fix our floating Anschaunng (Cassirer 1929: 471). In the third volume of the "Philosophy of Symbolic Forms" Cassirer defined perception as an objectivation that constructs invariants. Hence, the process of cognition, or knowledge fix the permanent flux of the continuum that surrounds us by placing invariants. ${ }^{12}$ With those invariants we perceive heterogeneous gestalten. If we have designated these gestalten and have conceptualized them to ideas, we have built up a reference cluster. Premise is, however, that the heterogeneous forms can be transformed into each other; shortly, they are congruent

9 In my lectures series I tried to compare Cassirer's cultural anthropology that relies upon a Sprachwelt with Bateson's ecology. For lack of space, I here just quote Cassirer: "All theoretical cognition takes its departure from a world already preformed by language; the scientist, the historian, even the philosopher, lives with his objects only as language presents them to him" (Cassirer 1925: 28).

10 "In der Gegenwelt sind die Gegenstände der Umwelt durch Schemata vertreten, die je nach dem Organisationsplan des Tieres sehr allgemein gehalten sind und sehr viele Gegenstandsarten zusammenfassen können. ... Die Schemata sind kein Produkt der Umwelt, sondern einzelne, durch den Organisationsplan gegebene Werkzeuge des Gehirnes, die immer bereitliegen, um auf passende Reize der Aussenwelt in Tätigkeit zu treten. ... Die Schemata wechseln mit den Bauplänen der Tiere" (Uexküll 1921: 168-169).

11 "It seems that the interface between nerve and environment is characterized by a deep difference in kind, i.e. in logical typing, between what is on one side of the interface and what is on the other" (Bateson, Bateson 1987: 123).

12 "Invariants are never any objects, but just specific basic relations and functional interdepencies that we humans fix by the symbolic language of mathematics and physics in equations" (Cassirer 1921: 42; 1929: 471). 
to each other. In other words, we humans are capable to convert groups or gestalten because we map perception groups into cluster terms whereby we observe structures. That means, we are anchoring the transient Anschauung with a grid that we envelope upon our intuitive categories. At that very moment the floating is come to an end, and the real world is trapped into a system of differentiating symbols.

As soon as we have defined an object or event that we are perceiving, we have cut out of nature's collection a phenomenal entity. Due to the cut, or as philosophy says, due to the ontic separation, we can observe what happens on our side of the cut, and we might guess what happens on the other side of the cut - so far Bateson's hope. Premise is that something that is on the other side, has meaning that will diminish the probability of wrong guessing. Crucial is, however, how to position the information per se inside the huge lake of redundant messages or differences whilst it does not matter to which side we are referring. Bateson who purposed to eliminate this confusion, identified redundancy and meaning as if both belong to one and the same discoursive world. Inside our small universe, being full of meaningful messages, redundancy is part of a meaningful world which encloses the intercourse and the extensional connections as well. But, how should we think of the purpose and/or function of the communicative cognition representing our consciousness?

For Bateson cognition couples ourselves as residents of the environment definitely to the ecosystem at large. Thus, it corresponds to the interrelationship of object to system, or to the whole of nature as Uexküll has pointed out in more poetic words in his Umweltlehre. Uexküll's model shows that human monads ${ }^{13}$ whirl around between a specific Merknetz and Wirknetz, and act in their own closed shells called environment. This environment that is based on the Kantian category of space, is a construct of every living organism configuring their own inner world. ${ }^{14}$

\footnotetext{
13 The allusion to Leibniz is conscious. A monad reflects the whole contents of the world because it is a self-identical entity. Therefore, it does not divide itself to a subject-object relation. For a critique of the monadic perspective, cf. Willard van Orman Quine, the mathematical holist.

14 For a further analysis of Uexküll's notion of environment and how it depends on our tactile and visual perception, cf. Brauckmann (2001) and Kull (1998).
} 


\section{Mind and its learning levels}

Based on his experimental data on the communication of dolphins and the learning process of computers, rats, and humans in exact this sequence, Bateson developed a type hierarchy of learning. To anticipate one of Bateson's statements on learning, it reveals a kind of qualitative progression, or, to use his terminology, it is a change of ideas. It is closely modelled to Russell's type hierarchy and Goethe's ideal morphology. The name of the latter might be too eccentric to be mentioned in this context. However, Goethe also formulated a typological classification when describing the Urpflanze that makes a difference: A stem is what has leaves, a leaf is what has buds, a bud is what has a pistil, a pistil is what has carpels, and a carpel is what has an ovary, style and stigma and so on until you finally imagine the idea representing the Urpflanze.

We will start our discussion on Batesonian learning with a few sentences on mind and its meaning when explained from a typological perspective. Without mind, you cannot learn as you have been taught. It is for sure that Bateson would doubt the statement. As the reader might already expect, the mind is somehow inspired by the concept of differences embodying our categorical patterns. Hence, our mind operates like an assembly of mental processes that are caused by differences which conversely are correlated to the transient alterations of negentropy and entropy. ${ }^{15}$ This concretely means that mental processes demand for circular, or even more complex chain causation determining the divergent states of our mind. By doing so, they create effective differences that correspond to meaningful information, and code versions of the preceding operations that are already stored in our memory a long time ago. Then the primary differences are converted to transmutations the operation rules of which are relatively constant.

The description and classification of such processes corroborate a hierarchy of logical types being immanent of the phenomena and our mind as well. Unfortunately, Bateson apparently did not consider the difference between ontology and epistemology — or has he seen beyond it? In his ecology, cognitive notions and ontic phenomena that we call thinking, evolution, ecology, life, or learning, are only occurring in systems satisfying those criteria. As our mind is a classificator

To avoid misunderstandings, Bateson here points implicitly to probability and statistics, and not to the thermodynamics of irreversible processes. 
of logical types, learning will codify differences to patterns since otherwise it would violate the rationality of the Batesonian theory.

First, Bateson distinguished four different levels of learning that starts on the level zero. Zero-learning can be carried out even by simple mechanical devices as a thermostat. When an individuum receives a signal, for example, a sensory input that is repeated over a certain time, the individuum will show a minimal change in his or her reactions. The zero-level is not stochastic, or to say it from the other side, this learning cannot correct itself by trial and error. After Bateson had worked with dolphins for some years, he extended the concept of zero-learning slightly. Now the relationship between two or more organisms represents the sequence of a stimulus-response series which forces zero-learning to evolve to Learning I. On this learning level we acquire further skills by actively changing a received signal; this is called Learning I, induced, for example, by punishment and reward, or by Pavlovian conditions. It still resembles a kind of mechanical learning that even organisms without a nervous system can carry out. However, even at this primitive state of learning, a frame of reference or context is implicated. Furthermore, it is assumed that a context which can be repeated, symbolizes a pattern-like something informing the organism what for a set of alternatives, whether there are right or wrong, it might opt for. As it might easily been seen, Learning I corrects the results obtained on the zero-position.

When an organism is qualified to modify the knowledge that was acquired on the level of zero-learning and was trained by Learning I, it has arrived at Learning II, or deutero-learning. Then the context as it was perceived will have been changed. In Bateson's cybernetic model, Learning II generates the linear learning of the preceding stages to information sets that enable us to order patterns and to reflect our knowledge. Again, after Bateson had gained more experimental data on the behaviour and learning of dolphins, he revised it. Now deuterolearning prepares us humans to achieve knowledge about the patterns that structure context contingencies which have occurred at Learning I. The revision was necessary for realizing the analogy between a computer as thinking machine and the human brain as operator of differences. Consequently, he insisted that any receipt of information is, in a broad sense, learning. It may sound as if Bateson mapped the calculating machine to imaginative brains, but please beware of it - it is just an analogy, and not an existential proposition as Artificial Intelligence Research has stated it. 
This third step of learning will modify the character of the individuum because it creates a pattern belonging to one person in that twoperson system which constitutes a context of learning. Bateson extrapolated his model further arguing that living organisms are constrained to accumulate deutero-learning and, therefore, to create hierarchies of knowledge. By it, we are mapping the pattern contexts of the earlier steps of learning processes to our knowledge and try to rationalize the antinomies resulting from the process of deuterolearning. This leads finally to Learning III, the realm of cognition.

The central point of his epistemic anthropology is the concept of deutero-learning that refers to a knowledge "every schoolboy knows", namely, you learn for gaining knowledge and habits that distinguish yourself from any other person. As it exists and functions, at least sometimes, mental states as the free will and operational thinking, exist, too. It corresponds to the assumption that there is a set of cognitive habits based on awareness to which mental states will relate without converting themselves at each time to memory. To fully comprehend this statement, one has to recall that for Bateson memory evidences a stream of events, floating around without fixed boundaries such that it is reshuffled again and again, always adjusted to the here and now. To say it in other words, you can identify deutero-learning as the mental state before the knowing of patterns and after trivial learning presupposing a kind of proto-learning. The proto-learning is characterized as the quantitative increase of a simple learning curve which alterates to deutero-learning by a slow progression. The progression starts from a Pavlovian framework and improves by trialand-error mechanisms to that stage on which the contexts we have learned, help us to avoid wrong decisions, or to gain wrong information. To be honest, there are some minor problems to believe in it. The most important one is that we humans do not like always to behave like rational animals.

One by-effect of his type hierarchy of learning is that the genetic determinism is pushed aside because we can achieve levels of knowledge that free us from the micro-deterministic constraints imposed upon us by our genetic constitution. The result of a permanent learning process is a kind of evolution. Bateson himself stated that if there exists a fixed scheme of how we think, the evolutionary system will be able to select positive decisions. Such a scheme is either located 
inside genes or between them. ${ }^{16}$ Bateson's sentences indicate that not all possible choices are placed on the same level; quite the opposite, you will find them distributed on a hierarchy of different stages. That is the main reason why redundancy is emerging, or to say it in Batesonian terms, the predictability of particular events inside a complex system will increase.

Analogous to the levels of learning Bateson deduced three cognitive types that are congruent to specific neurophysiological structures. They are based on the mental curves that classify the learning hierarchies and map the neuronal synapses to the contexts of our mental actions. In other words, in our brain contingent permutations directing and controlling the nervous system are emerging. By a selective process of energetic amplification and elimination, our mental states adjust the constraints of the environment in such a way that they are finally feasible to our logical categories. Conversely, the patterns are regulated by the physical outerworld that surrounds us and every living organisms, animals and plants as well, and that is independent from our interventions or our perceptions. ${ }^{17}$ Bizarre as it might sound, for Bateson we humans or animals or plants consist of simple energy transferring system belonging to an integrated eco-cybernetics called Nature.

In his theory the progress of science corresponds to the trails of fuzzy thinking structuring itself slowly upon a more or less ungrounded base. Such a base is, part by part, underpinned by rational operations that set interfaces and correct the shadowy fundament. The

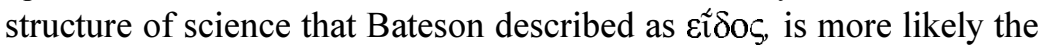
same in all different disciplines. This assumption is mainly based on the General System Theory as developed by Bertalanffy stating that we can transfer scientific results from one discipline to another because we are dealing with analogies. ${ }^{18}$ For Bateson the analogies, primary relations and secondary relations as well, are produced by information processes of the type hierarchy of learning.

\footnotetext{
16 Maybe, you can locate it inside the immune system as Niels Jerne has proposed in comparing his network theory of the immune system to the generative grammar of Chomsky, cf. Brauckmann (1999) for a short discussion how Jerne's network theory of immunology relates to biosemiotics.

17 The difference between environment and surroundings marks the cornerstone of Uexküll's Umweltlehre, cf. Kull (1998).

18 Cassirer characterized this transfer as the fruitful result of categorical faults.
} 


\section{Communication}

Bateson's simplification of Russell's formal type hierarchy is based on his hypothesis that there exist a difference between the context itself and the operation which demarcates the context in question from other patterns. As an example for the relationship of context and message the elephant may serve: Let us imagine the trunk of an elephant. For the elephant it is its nose. The trunk is a nose because of a communication process for its context identifies it as a something that is placed right in the middle of two eyes and a mouth. And such a thing, we call a nose. In other words, the context determines how an information is coded. In fact, we are talking of a metacommunication in the sense of Whorf. The metacommunication serves to classify messages which are embodied in the context. Furthermore, it constitutes and explains the linguistic standards to which message and context refer. And therefore, beware of the message, it is not what it causes. If you do not consider this warning, you might be caught in the trap of double-binds that simulate from a psychiatric perspective the troubles Russell and Whitehead encountered when cleaning up the antinomies of traditional logics. As it is well known, they tried to purify logics from all the disturbances caused because we humans liked to confusing logical types, not to say, we all, sometimes more, sometimes less, celebrate the homo ludens in ourselves. It pleases us to categorize objects, phenomena, or events falsely, particularly when doing it on a very high level of abstraction. However, logics was finally [?] thought to be saved for all these paradoxa enjoying philosophical clowns.

Communication, as Bateson understood it, is furnished by some premises that will be shortly described now. The first one is the Freudian postulate that only limited aspects of a part of what happens in human communication are accessible to the consciousness of the participants. Bateson used the image of Rilke's unicorn to sketch the phenomenon of the unspeakable context. ${ }^{19}$ When discussing the enigma of communication at the Advanced Institute of Behavioral

\footnotetext{
19 "Rilke's Unicorn is present in every conversation between persons and this fictitious beast evolves and changes, dissolves and is recrystalized in new shapes with every move and message. Denial of the Unicorn will not prevent its existence - but only cause it to become monstrous" (Bateson 1971: 20). Although Bateson quotes Rilke's Sonette an Orpheus, Teil 2, Sonett 4, he hides the other Unicorn that was of utmost importance for his theory, namely Carroll's Unicorn appearing behind the looking-glass.
} 
Sciences of Stanford in the 1950s, he referred explicitly to Sapir's definition of the unconsciousness as a necessity of the economics of hierarchic organization - a concept which was at the bottom of his own theory of communication. ${ }^{20}$ The difference to the Freudian approach rest upon the emphasis upon communication and perception. However, Bateson agreed to Freud that all messages - whether verbal or non-verbal - are mediated in their creation by a primary process, i.e., they contain multiple references characterizing our commitment to dream and fantasies.

Another premise was the discontinuity of our experience, a basic statement of Gestalt psychology. It emphasizes the hierarchy of subdivisions typical of the perception process that results in multiple coding. The mentioned multiplicity can effect a code distortion when the persons involved differ in their explicit and implicit rules of coding the phenomena or entities they perceive. Bateson concluded therefore that the rules of self-perception controlling the formation of our selfimage, are very often modified by the way in which others apprehend our messages - double-binds are lurking behind the mirror. If other persons cannot transform our messages into information that makes a difference, the communication has failed. When such a failure will be repeated again and again, it will at least affect our behaviour, then our habits and our individual constitution, maybe even until we become cases for pathogenetic investigations.

An important notion of his communication model is the type - it might not surprise anymore. How did Bateson now define types? Types are communication levels that are enmeshed into each other, and at the same time they are used to be built upon hierarchies structuring the communication. As can be easily seen, this double structure and twofold function will cause some additional troubles. Hence, we all know because we were trained to know, there exists a difference between nomina and the referential process, the system and the genesis, the analogous and the digital. To solve it, Bateson tried to knot the digital procedures - that is the traditional denomination - to the analogous procedures. His point of departure was the logical principle that the process of denomination itself can be nominated; to say it simpler, Bateson replaced the ladder of logical types that resulted from

\footnotetext{
20 "It was Sapir's genius to recognize that culture, language, and personality form an interacting system and that this system in turn interacts with the biological givens of perception to generate cognition" (Rieber 1989: 19). Whether it is a sign of geniality to stating the obvious, I really doubt.
} 
the Principia, by attributing an inherent evolution to the context. ${ }^{21}$ However, you cannot say that the epistemic ecology became simpler when adding the time dimension; quite the opposite, it all became more complicated.

According to Bateson communication systems are hierarchically structured, and the verbal description of such an organization rests in most cases upon visual perception converted into linguistic patterns. What did he want to confirm with such a strange statement? His main objective was to refute the reductionistic hypothesis, non-verbal (visual) communication that is based on mythical or religious thinking, would be an evolutionary residuum without any meaning for us, modern and civilized as we ourselves claim to be. Bateson's problem was that he rationalized all what in effect cannot be rationalized, and applied mythical thinking to all what is rational, or to all that appears to be rational. Thus, he really talked myth. The crucial problem concerning a philosopical theory of myth in general, is that myths operate by actions. They very often cannot be abstracted to conceptual images which we try to communicate by ordinary language. You inwardly experience and feel a myth, and if you try to put it in proper words, it becomes mere a not yet fully rationalized fiction which is categorized by the belief that its designated sign exists really as an object. Mythical narrative requires a specific way of perceiving, that does not comprehend nature as an objective existence located a world apart. For Bateson, the myth performs a scheme to orient life in general, it interprets our world based on feelings and sensation. Thus, it represents the mother soil for symbolic forms on which, if language and technics are added, science and art can emerge.

In his ecological model, this specific modus of communication fulfils purposes quite different from the verbal language. And it does so since the world of communication contains messages, and it does not consist of well-defined objects which belong to the kingdom of pure mathematics. Concerning the issue, to which scientific discipline Bateson's ecology of communication, or message and difference belong, he himself set it apart of the canon of science and construed it with referring to the anthropological concepts of context and meaning. Therefore, Bateson's ecological epistemology has some similarities to Berkeley's universe of phenomena although even Berkeley himself has underestimated the point, as Bateson conceeded. Maybe, a better

\footnotetext{
21 Bateson stated for his own development that he was deeply influenced by his father who did not appreciated Darwinian evolution.
} 
idea would have been "in this context" if Bateson had connected his approach to Uexküll's ethological aesthetics serving as the visual cue that plays definitely a great part in our understanding of the environment.

\section{Double-bind}

A decisive step to his double-bind theory was done when Bateson discovered the conception of the "map-territory" that Alfred Korzybski formulated in a monograph of nearly thousand pages. According to Korzybski reasoning, perception and the communication on perception transform and code the ideas, the perceived objects and phenomal signs, whereby the report maps the objects in question. By doing so, all methods of coding are subsumed under the iconic pars pro toto relationship that couples concepts, objects, and phenomena to each other on quite different ways. As a consequence, the operation to classify all of the communicative material has to be controlled at each state of communication whether it is the map or the territory. Thus, it is evident, or it should be obvious at least, that message and context implicitly refer to the same level constituting and explaining both of them. Should we call this level the difference? In one talk on game theory Bateson asked the audience when a sign will be recognized as a signal, and answered it that it will be known because the sign-objects are communicated on a metalevel - and again, we are sitting in tautology's trap.

If the specific communication levels that are codified as logical units and typify a message, are disturbed by misunderstandings or, even worse, by contractions between speech and action, an additional context will appear that ascribes the typifier in a wrong way to the concerned message. And if further this confusion will become a permanent habit of our person since message and context are falsely related to each other again and again, strong psychoses can infect you and maybe change your individuality. In 1961 Bateson edited and introduced the notebook of a schizophrenic, Perceval's Narrative which shows how the world of a schizophren is structured completely by double-binds. In the schizophrenic's world the apparent coherence of logics that our mind can process, is broken up. To explain this sharp 
argument, you have to think about Bateson's attitude towards the syntactical first person, the $I c h .^{22}$

Like Schopenhauer, Bateson denied an objective existence of the Ich since it is present in the world of communication alone. By it, he avoided the solipsism of philosophical phenomenology as formulated by Husserl. ${ }^{23}$ For Bateson's ecological approach the Ich is an essential member of the syntax that covers its own experience and the life of its fellow Ichs on which its well-being depends. To put it into other words, between context - whether it is a speech or an action - and messages, or between meta-message and message there exists the same gap that you can discover between an object and the word assigned to it. That means simply you need a bridge to cross the river of difference that floats between both. And even worse, per definitionem both belong to different hierarchical levels. Thus, you are forced to climb, too. Seriously, as we all live our lives as a zoon politikon, we desperately need conceptual and commonly accepted notions to describe the perception states of other persons if we want to experience these states with our own body. ${ }^{24}$

Due to his double-bind concept Bateson focused even more than he had done before on the human observer whom he set right into the centre of the observation process. Such a focus presupposes that the entity to be investigated represents an infinite regress of references that will never transform to the object itself - a statement corresponding to his attitude towards the $I c h .^{25}$ The nucleus of the doublebind theory stated that beyond every single message is hidden a context which conditions the message and effects our actions. The double-binds that support trans-contextual syndroms, function like the bridge offering us a pathway over the tissue, woven of contexts and

22 Here the German idiom Ich for the English $I$ is consciously chosen because the plural of the English $I$ reminds of German eggs - no doubts, they are objects, but not the subject addressed here.

23 For the scientific attitude cf. Schrödinger's attitude: "Pour être bref, je designerai l'hypothese qui s'oppose au solipsisme par lettre $P$ (personalitè des creatures qui m'entourent)" (Schrödinger 1935: 186).

24 "Eine recht radikale Folgerung daraus ist, dass das Innere (Psychische, Mentale), also das eigentlich privat, intern Zugängliche nur mittels der äusseren Sprache und ihrer sozial bestimmten Bedeutungszuordnungen dargestellt (repräsentiert), differenziert, gemeint und begriffen werden kann. Das klingt geradezu paradox" (Lenk 1994: $38)$.

${ }_{25}$ "In communication exchange, there could be no quantities or substances, however, only transformations of patterns. [...] I acquire in my mind no double bind but only a percept or transform of a double bind" (Bateson 1972: 272). 
messages. Obviously, his double-bind theory is based on the model of deutero-learning emerging from the crucial problem of Verdinglichung [objectivation].

\section{Ecology of mind}

Now context and message are even more interwoven than ever before. As already said, the mind consists of transformations, phenomena, events and the rules which transform the former. To recapitulate shortly, Bateson defined the mind from a systemic standpoint and, at the same time, from a genetic perspective. According to evolutionary theory, all biological systems are capable of an adaptive modification initiated by a feedback that results from the transient operations of trial and error. To say it in more biological terms, they obey the Tibetian pray mill murmuring selection-adaptation-mutation. Those actions, conversely, create a superimposition that connect the numerous feedback loops mutually. Thereby mental habits are shaped which qualify us to problem solving. And here we are - standing again on the level of deutero-learning.

Ecology here - it seems to be meaningless to say anymore in this context - is characterized as a classification modus, i.e., an operation that is executed by the whole system consisting of an individual, a computer and the environment. And exactly this encompasses ecology of mind. For example, a specific information set is transferred by the mind, this is what Bateson called the screening of the consciousness to curves of mental moments. One idea after the other is systematically selected by an unconscious process of perception that is performed by our mind. A formal feature of this mental operating is the aiming towards a steady state that couples body, mind and ecosystem in harmony. During this process the system is learning. That means, in mutually crossed loops phase alterations are effected by the environment and then distributed very slowly through the whole ecosystem. Bateson has described it as the behaviour of vicious systems escalating over their circuits; maybe an overshot will be the best image to describing it. To sum up shortly, the minimal demands for an ecological system of mind that should be fulfilled are the following conditions:

1. The system consisting of our mental states and the external environment works on the basis of differences; 
2. the system consists of closed, but dynamic networks resulting from differences and transformations of differences;

3. many events inside the system are fed more likely by a reacting component than by the influence of the triggering component with energy;

4. there exists self-regulation, or self-correctiveness, as Bateson emphasized, towards homeostasis.

\section{Conclusion}

Bateson's wanted to discover the patterns that connect the physical world of pleroma ${ }^{26}$, and of creatura. In the universe of the former, the forces and effects explain sufficiently events, but inside the creative universe you cannot apprehend without considering the semantic differences imposed upon us by the environment. To transfer these different worlds to Bateson's ecological theory, he talked in the terms of pleroma in addressing mythical creatura. Unfortunately, he was too occupied with the formal origins of order which he understood as a problem of recursive-like operations. The ecology of mind represents an epistemology based on anthropological and ethological field studies and, at the same time, on cybernetic research. His contextual epistemology symbolizes an eco-systemic perspective of living processes that envelopes the individual mind, the pathways and messages outside the body, the interconnected environment and the planetary system. He held an epistemological holism that is exaggerated by a cybernetic terminology - and that is the elegance of his theory as its pitfalls, too.

Therefore, I should confess that I am more than dubious about imposing a formal logical style hierarchy of logical types on the human style of thinking. For me, we are not nearly as rational as Bateson suggests. His epistemic ecology is, however, sympathetic for me, because he burnt his fingers by putting them to many rusty conceptual approaches, mental habits, ways of perceiving and relational patterns. In the gestalt of a leaf, in the body of a cancer, in the grammar of our language he discovered comparable messages that patterns our world. If you translate Bateson's pattern into existential terms, then you will see the myth as the structure that patterns human events. A few centu-

26 Pleroma openly refers to Jung's ideas, but Bateson understood this mystical notion in a pre-Jungian sense. 
ries ago it would have been called pantheism. No doubt, helpful here was his immense scientific imagination and his maxim of reasoning to think strictly and loosely simultaneously.

How does it all fit together? To answer with Batesonian words, it is the idea that the contrast between part and whole as soon as such a contrast appears in communication is just one of the logical types, but never one of reality. The whole is always related to its parts on a metalevel - my addendum here is, on the metalevel of a communication model of cognition. Are there any questions left? I really hope so, except the initial question asked at the beginning, namely, how Bateson's cognitive ecology fits the holistic principles of emergent macroproperties, the holistic feedback, an approximate separation, the nonpredictiveness, and the moral value. This question was implicitly answered again and again on the preceding pages.

\section{References}

Bateson, Gregory 1936. Naven: A Survey of the Problems Suggested by a Composite Picture of the Culture of a New Guinea Tribe Drawn from Three Points of View. Cambridge: Cambridge University Press.

- 1961. Perceval's Narrative: A Patient's Account of his Psychosis, 18301832. Reprint edited and introduced by G. Bateson. Palo Alto: Stanford University Press.

- 1971. Communication. In: McQuown, Norman A. (ed.), The Natural History of an Interview. Chicago: University of Chicago Library Microfilm Collection of Manuscripts on Cultural Anthropology [no. 95, series IV], $1-40$.

- 1972/2000. Steps to an Ecology of Mind: Collected Essays in Anthropology, Psychiatry, Evolution, and Epistemology. San Francisco: Chandler Publishing Company.

- 1979a. Mind and Nature: A Necessary Unity. New York: Dutton.

- 1979b. The Science of Knowing. Esalen Catalog 17(2): 6-7.

Bateson, Gregory and Bateson, Mary Catherine 1987. Angels Fear: Towards an Epistemology of the Sacred. New York: Macmillan.

Bateson, Gregory and Mead, Margaret 1942. Balinese Character: A Photographic Analysis. (Special publication of the New York Academy of Science, vol. 2.) New York: New York Academy of Sciences.

Brauckmann, Sabine 1999. On genes, cells and memory. Semiotica 127(1/4): 151-167.

- 2001. From the haptic-optic space to our environment: Jakob von Uexküll and Richard Woltereck. Semiotica (Special issue: Jakob von Uexküll: A Paradigm for Biology and Semiotics, in print). 
Cassirer, Ernst 1921/1994. Zur Einsteinschen Relativitätstheorie. In: Cassirer, Ernst. Zur modernen Physik. 7. unveränd. Auflage. Darmstadt: Wissenschaftliche Buchgesellschaft, 3-124.

- 1929/1996. The Philosophy of Symbolic Forms. Vol. 3: The Phenomenology of Knowledge. (Translated by Ralph Manheim, pref. and introd. by Charles W. Hendel.) New Haven: Yale University Press.

- 1925/1953. Language and Myth. (Translated by Suzanne K. Langer.) New York: Dover.

- 1979. Symbol, Myth and Culture: Essays and Lectures of Ernst Cassirer, 1935-1945. Verene, Donald Phillip (ed.). New Haven: Yale University Press.

Carroll, Lewis 1899. Through the Looking-Glass and what Alice Found There. London: MacMillan.

Davidson, Donald 1980. Mental events. In: Davidson, Donald. Essays on Actions and Events. Oxford: Clarendon Press, 207-222.

Fechner, Gustav Theodor 1873. Einige Ideen zur Schöpfungs- und Entwicklungsgeschichte der Organismen. Leipzig: Breitkopf u. Härtel.

Frede, Dorothea and Schumacher, Reinhold (eds.) 1997. Ernst Cassirers Werk und Wirkung. Darmstadt: Wissenschaftliche Buchgesellschaft.

Harries-Jones, Peter 1995. A Recursive Vision: Ecological Understanding and Gregory Bateson. Toronto: University of Toronto.

Heidelberger, Michael 1993. Die innere Seite der Natur. Gustav Theodor Fechners wissenschaftlich-philosophische Weltauffassung. Frankfurt: Klostermann.

Jerne, Niels 1985. The generative grammar of the immune system, Bioscience Reports 5: 439-451.

Kant, Immanuel 1790/1975. Kritik der Urteilskraft. In: Kant, Immanuel. Werke, vol. 5. Weischedel, W. (ed.). Darmstadt: Wissenschaftliche Buchgesellschaft, 237-620.

Korzybsky, Tadeusz 1941. Science and Sanity. New York: Science Press.

Krois, John M. 1981. Peirce and Cassirer: the philosophical importance of a theory of signs. In: Ketner, Kenneth L.; Ransdell, Joseph M.; Eisele, Carolyn; Fisch, Max H. and Hardwick, Charles S. (eds.), Proceedings of the Charles S. Peirce Bicentennial International Congress. Lubbock: Tech University Press, 99-104.

Kull, Kalevi 1998. On semiosis, Umwelt, and semiosphere. Semiotica 120(3/4): 299-310.

Lenk, Hans 1994. Von Deutungen zu Wertungen: Eine Einführung in aktuelles Philosophieren. Frankfurt: Suhrkamp.

Lipset, David 1980. Gregory Bateson: The Legacy of a Scientist. Englewood Cliffs: Prentice Hall.

May, Rollo 1977. Gregory Bateson and humanistic psychology. In: Brockman, John (ed.), About Bateson. (Essays on Gregory Bateson by Mary C. Bateson, Ray Birdwhistell, John Brockman, David Lipset, Rollo May, 
May, Margaret Mead, Edwin Schlossberg, with an afterword by Gregory Bateson.) New York: Dutton Paperback, 75-99.

Quine, Willard van Orman 1987. Quiddities: An Intermittently Philosophical Dictionary. London: Penguin.

Rieber, Robert W. 1989. The Individual, Communication, and Society: Essays in Memory of Gregory Bateson. Cambridge: Cambridge University Press.

Ruesch, Jürgen and Bateson, Gregory 1951. Communication: The Social Matrix of Psychiatry. New York: W. W. Norton.

Sapir, Edward 1927/1949. Selected Writings of Edward Sapir. Mandelbaum, D. G. (ed.). Berkeley: University of California Press.

Schrödinger, Erwin 1935. Quelques remarques au sujet des bases de la connaissance scientifique. Scientia, 57: 181-191.

Uexküll, Jakob von 1921. Umwelt und Innenwelt der Tiere. 2. Auflage. Berlin: Springer.

- 1940. Bedeutungslehre (BIOS. Abhandlungen zur theoretischen Biologie und ihrer Geschichte, sowie zur Philosophie der organischen Naturwissenschaften, Bd. 10.) Leipzig: J. A. Barth.

Whorf, Benjamin Lee 1952. Collected Papers on Metalinguistics. Washington: Foreign Service Institute.

\section{Шаги к экологии познания: холистическое эссе}

Эссе информирует о холистическом подходе Грегори Бейтсона к эпистемическому рассмотрению природы. Экология разума опирается на биологический холизм, служаший методическим средством объяснения “феноменов" жизни, таких как, например, коммуникация, обучение, познание. Начав с идеи, мельчайшей единицы информации, Бейтсон разработал классификацию обучения, основанную на кибернетическом подходе к разуму. Коммуникационная модель сосредоточена на парадоксах, обусловленных ложной сигнификацией. Она ведет к патогенезу шизофрении, определяемой в рамках концепции двойных посланий. Эта экосистемная перспектива по отношению к живым процессам представляет истинно холистическую теорию природы. 


\section{Teadvustuse ökoloogia poole: \\ holistlik essee}

Essee annab ülevaate Gregory Bateson'i holistlikust lähenemisest episteemilisele loodusvaatele. Mõistuse ökoloogia tugineb bioloogilisele holismile, mis on elu "fenomenide", — nagu näiteks kommunikatsioon, õppimine, tunnetus, - seletamise metoodiliseks vahendiks. Alustades ideest, vähimast informatsiooniühikust, töötas Bateson välja teadvusele küberneetilisel lähenemisel põhineva õppimise klassifikatsiooni. Kommunikatsioonimudel keskendub väära tähistamise poolt põhjustatud paradoksidele. See viib skisofreenia patogeneesini, mida määratletakse topeltseoste kontseptsiooni raames. Taoline ökosüsteemne elusprotsesside käsitlus esindab tõeliselt holistlikku(terviklikku) loodusteooriat. 